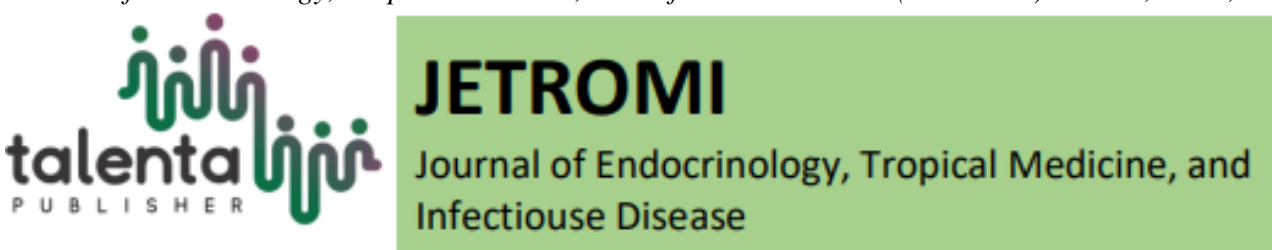

\title{
The Etiologies of Pediatric Acute Respiratory Distress Syndrome (PARDS) in Patients Treated at The PICU of Haji Adam Malik Hospital Medan in 2017 - 2020
}

\author{
Dea Ayunda ${ }^{1}$, Ririe Fachrina Malisie ${ }^{2}$, and Ahmad Yapiz Hasby ${ }^{3}$ \\ ${ }^{1}$ Faculty of Medicine, Universitas Sumatera Utara, Medan, North Sumatera, Indonesia \\ ${ }^{2}$ Department of Pediatric, Universitas Sumatera Utara, Medan, North Sumatera, Indonesia \\ ${ }^{3}$ Department of Anesthesiology and Intensive Therapy, Faculty of Medicine, Universitas Sumatera Utara, \\ Medan, North Sumatera, Indonesia
}

\begin{abstract}
Background. Pediatric Acute Respiratory Distress Syndrome (PARDS) is considered to occur due to direct lung injury and indirect lung injury. The research aims to describe the causes of PARDS in patients treated at the Pediatric Intensive Care Unit (PICU) of Haji Adam Malik Hospital Medan in 2017-2020.

Method. This type of research is a retrospective descriptive study with a cross-sectional study design uses secondary data in the form of medical records. The population of this study were all PICU patients aged 1 month - 18 years at Haji Adam Malik Hospital Medan in 2017-2020 using consecutive sampling technique.

Results. Of the 100 PICU patients, there were 55 male patients with the most age group was $<12$ months. The most common mode of ventilation used is 80 invasive mechanical ventilation and duration of ventilation used has a mean value of 17.72 days. A mean value of Length of stay (LOS) patient was 25.47 days. Based on the Oxygenation Index (OI), of the 80 patients with invasive mechanical ventilation, most patients were 57 at risk PARDS, meanwhile, based on Oxygen Saturation Index (OSI) categories, of the 20 patients with noninvasive mechanical ventilation, most patients were 15 at risk PARDS. Most caused by indirect lung injury, namely 51 (51\%), direct lung injury 47 (47\%), and due to complications of using a ventilator as much as $2(2 \%)$.

Conclusion. The most common direct lung injury factor is the primary pulmonary infection, aspiration, trauma, and other factors. The most common indirect lung injury factor is sepsis, then central nervous system (CNS) disorders, postoperatively, and other factors.
\end{abstract}

Keyword: etiologies; PARDS; pediatric; PICU; respiratory distress

\begin{abstract}
Abstrak
Latar belakang. Pediatric Acute Respiratory Distress Syndrome (PARDS) dapat terjadi karena beberapa faktor penyebab dari dalam paru serta penyebab dari luar paru.Penelitian ini bertujuan untuk mengetahui gambaran faktor penyebab PARDS pada pasien yang dirawat di Pediatric Intensive Care Unit (PICU) RSUP Haji Adam Malik Medan tahun 2017-2020.

Metode. Jenis penelitian ini adalah deskriptif retrospektif dengan desain studi cross-sectional yang menggunakan data sekunder berupa rekam medis. Populasi penelitian ini adalah seluruh pasien PICU usia 1 bulan - 18 tahun di RSUP Haji Adam Malik Medan tahun 2017-2020 dengan teknik pengambilan sampel menggunakan consecutive sampling.
\end{abstract}

*Corresponding author at: Faculty of Medicine, Universitas Sumatera Utara, Medan, North Sumatera, Indonesia

E-mail address: deaayundaa18@gmail.com 
Hasil. Dari 100 pasien PICU, dijumpai 55 pasien laki-laki dengan kelompok usia tertinggi adalah $<12$ bulan. Mode ventilasi yang paling sering digunakan adalah ventilasi mekanik invasif sebanyak 80 dan durasi penggunan ventilator pasien PICU memiliki nilai rata-rata 17,72 hari. Nilai rata-rata lama perawatan pasien PICU adalah 25,47 hari. Berdasarkan kategori Oxygenation Index (OI), dari 80 pasien dengan ventilasi mekanik invasif dijumpai paling banyak anak dengan ancaman gagal napas yaitu 57 orang, sedangkan berdasarkan kategori Oxygen Saturation Index (OSI), dari 20 anak dengan ventilasi mekanik non-invasif dijumpai 15 anak dengan ancaman gagal napas. PARDS paling banyak disebabkan karena faktor dari luar paru yaitu 51, dari dalam paru 47, dan karena komplikasi penggunaan ventilator sebanyak 2 .

Kesimpulan. Faktor penyebab dari dalam paru yang paling sering terjadi adalah infeksi paru primer, kemudian apirasi, trauma, dan faktor lain. Faktor penyebab dari luar paru tersering adalah sepsis, kemudian gangguan sistem saraf pusat (SSP), pascaoperasi, dan faktor lainnya.

Kata kunci: anak; gawat napas; PARDS; penyebab; PICU

Received 05 January 2022 | Revised 20 February 2022 | Accepted 28 February 2022

\section{Introduction}

Acute Respiratory Distress Syndrome (ARDS) was first defined as a syndrome characterized by tachypnea, refractory hypoxia, decreased lung compliance, and diffuse opacity on chest radiographs [1]. The incidence of ARDS is thought to occur due to a specific disease process which is divided into direct lung injury and indirect lung injury. Direct lung injury can be due to primary pulmonary infection, aspiration and trauma. Indirect lung injury such as sepsis, transfusion related (Transfusions Associated Acute Lung Injury/TRALI) and noninfectious systemic inflammation [2].

The incidence of ARDS in South America is around 10.1/100.000 people per year, in Europe 17.9/100,000 people per year, in Australia 34/100,000 people per year, and in the USA $78.9 / 100,000$ people annually [3]. The mortality rate from ARDS ranges from 35\% to $46 \%$. Survivors mostly experience severe physical, neuropsychiatric, and neurocognitive sequelae that can cause significant deterioration in quality of life for up to 5 years after the patient recovers from ARDS [4].

ARDS that occurs in children aged 1 month to 18 years is called Pediatric Acute Respiratory Distress Syndrome (PARDS). The Pediatric Acute Lung Injury Consensus Conference (PALICC) has established a definition for PARDS as shown in Table 1 below. 
Table 1. PALICC definition for ARDS [5]

\begin{tabular}{|c|c|c|c|c|}
\hline Age & \multicolumn{4}{|c|}{ Exclude patients with peri-natal related lung disease } \\
\hline Onset & \multicolumn{4}{|c|}{ Within 7 days of known clinical insult } \\
\hline $\begin{array}{l}\text { Origin of } \\
\text { edema }\end{array}$ & \multicolumn{4}{|c|}{$\begin{array}{l}\text { Respiratory failure not fully explained by cardiac failure or fluid } \\
\text { overload }\end{array}$} \\
\hline $\begin{array}{l}\text { Pencitraan } \\
\text { Dada }\end{array}$ & \multicolumn{4}{|c|}{$\begin{array}{l}\text { Chest imaging findings of new infiltrate(s) consistent with acute } \\
\text { pulmonary parenchymal disease }\end{array}$} \\
\hline \multirow[t]{3}{*}{ Oxygenation } & Non-invasive mechanical & \multicolumn{3}{|c|}{ Invasive mechanical ventilation } \\
\hline & $\begin{array}{l}\text { PARDS (No severity } \\
\text { stratification) }\end{array}$ & Mild & Moderate & Severe \\
\hline & $\begin{array}{l}\text { Full face-mask bi-level } \\
\text { ventilation or } \mathrm{CPAP} \geq 5 \\
\mathrm{CmH}_{2} \mathrm{O} \\
\qquad \mathrm{PF} \text { ratio } \leq 300 \\
\quad \mathrm{SF} \text { ratio } \leq 264\end{array}$ & $\begin{array}{l}4 \leq \mathrm{OI}< \\
8 \\
5 \leq \text { OSI } \\
<7,5\end{array}$ & $\begin{array}{l}8 \leq \mathrm{OI}<16 \\
7,5 \leq \mathrm{OSI}< \\
12,3\end{array}$ & $\begin{array}{l}\mathrm{OI} \geq 16 \\
\mathrm{OSI} \\
12,3\end{array}$ \\
\hline \multicolumn{5}{|c|}{ Special Populations } \\
\hline $\begin{array}{l}\text { Cyanotic Heart } \\
\text { Disease }\end{array}$ & \multicolumn{4}{|c|}{$\begin{array}{l}\text { Standard criteria above for age, timing, origin of edema and chest } \\
\text { imaging with an acute deterioration in oxygenation not explained by } \\
\text { underlying cardiac disease. }\end{array}$} \\
\hline $\begin{array}{l}\text { Chronic Lung } \\
\text { Disease }\end{array}$ & \multicolumn{4}{|c|}{$\begin{array}{l}\text { Standard criteria above for age, timing, origin of edema with chest } \\
\text { imaging consistent with new infiltrate and acute deterioration in } \\
\text { oxygenation from baseline which meet oxygenation criteria above. }\end{array}$} \\
\hline $\begin{array}{l}\text { Left } \\
\text { Ventricular } \\
\text { dysfunction }\end{array}$ & \multicolumn{4}{|c|}{$\begin{array}{l}\text { Standard criteria above for age, timing, origin of edema with chest } \\
\text { imaging consistent with new infiltrate and acute deterioration in } \\
\text { oxygenation which meet criteria above not explained by left } \\
\text { ventricular dysfunction. }\end{array}$} \\
\hline
\end{tabular}


ARDS is one of the most common diagnoses in critically ill children, and is the most common among all Pediatric Intensive Care Unit (PICU) patients, which is 1-10\%. Of 1000 children admitted to the PICU, 9-16 children meet the ARDS criteria [6]. In the 2019 Pediatric Acute Respiratory Distress Syndrome Incidence and Epidemiology (PARDIE) study, surveyed more than 23,280 PICU patients and 12,000 mechanically ventilated patients, of whom 744 (3.2\%) were identified as having PARDS based on the PALICC criteria. In the PARDIE study, the mortality rate of PARDS patients with mild or moderate non-invasive ventilation was the same (approximately 15\%), and mortality was higher in severe PARDS (> 30\%) [5]. A retrospective cross-sectional study conducted at the PICU of Dr. Moewardi General Hospital Surakarta from September 2016 to April 2017, there were 32 patients diagnosed PARDS with invasive ventilation. Out of 32 patients, 17 (53.1\%) were male and 11 (46.9\%) were female [7]. A study conducted at the PICU of Aga Khan University Hospital from July 2017 to June 2018, out of 150 patients, $23(15 \%)$ were having PARDS [8]. The most common causative factors were pneumonia or lower respiratory tract infection (63\%), followed by sepsis (19\%), aspiration (8\%), trauma (4\%), others (3\%), drowning (1\%), and shock non-sepsis (1\%) [2]. Respiratory failure is the most common cause of death in children admitted to the PICU with very varied causes, possibly due to various comorbid conditions and different etiologies [9].

Haji Adam Malik General Hospital Medan is the highest referral hospital in the field of specialization and subspecialty for the North Sumatra and Central Sumatra regions. This allows Haji Adam Malik Hospital Medan to treat quite a lot of PARDS patients compared to other hospitals. So with sufficient completeness of data, it is possible for researchers to conduct research at the Haji Adam Malik General Hospital Medan.

Based on the description above, researchers are interested in further research on the description of the causes of Pediatric Acute Respiratory Distress Syndrome (PARDS) in patients treated at the Pediatric Intensive Care Unit (PICU) H. Adam Malik Hospital Medan in 2017-2020.

\section{Methods}

This study used a retrospective descriptive research design with a cross-sectional study approach to describe the causes of Pediatric Acute Respiratory Distress Syndrome (PARDS) in patients treated at the Pediatric Intensive Care Unit (PICU) Haji Adam Malik Hospital Medan in 20172020. This research was conducted in the medical records section of the Haji Adam Malik Hospital in Medan from September to October 2021. The population in this study were all PICU patients aged 1 month - 18 years at Haji Adam Malik Hospital Medan in 2017-2020 as a inclusion criteria and the exclusion criteria were patient with incomplete medical record and patient with Covid-19. In this study, samples were taken using a consecutive sampling technique with criteria for etiologies are divided into two main groups, such as direct lung injury and indirect lung injury. The sample size taken in this study was determined using the Lemeshow formula.

$$
\begin{gathered}
n=\frac{Z^{2} \times P(1-P)}{d^{2}} \\
n=\frac{1,96^{2} \times 0,5(1-0,5)}{0,1^{2}}
\end{gathered}
$$

$$
n=96,04 \text { (rounded up to } 96 \text { samples) }
$$


Description:

$\mathrm{n}=$ Sample size

$\mathrm{Z}=$ Standard value of alpha. The value is obtained from the normal curve $\mathrm{z}$ table, namely 1.96

$\mathrm{P}=$ Proportion for a certain trait that is expected to occur in the population $(\mathrm{P}=0.50)$

$\mathrm{d}=$ Absolute precision or desired margin of error on both sides of the proportion $( \pm 10 \%$ or $\mathrm{d}=0.10)$

The data in this study are secondary data obtained from the medical records of children treated at the PICU of Haji Adam Malik Hospital in Medan in 2017 - 2020.

\section{Results}

For a period of 4 years, from 366 PICU patients who were admitted between January $1^{\text {st }} 2017$ to December $31^{\text {st }} 2020,100$ patients $(27.3 \%)$ met the inclusion criteria and were included in this retrospective study. Patients with incomplete medical record and patients with Covid-19 diagnosis were the exclusion criteria in this study. The demographic characteristics recorded in this study are gender, age, ventilation mode used, duration of ventilator use, and length of hospital stay. The distribution of demographic characteristics of pediatric intensive care unit (PICU) patients is presented on Table 2 below.

Table 2. Demographic characteristics of PICU patients

\begin{tabular}{lc}
\hline \multicolumn{1}{c}{ Characteristics } & Value $(\boldsymbol{n})$ \\
\hline Gender & \\
Male & 55 \\
Female & 45 \\
Age & \\
$\quad<12$ months & 41 \\
$1-5$ years & 25 \\
$5-10$ years & 10 \\
10-15 years & 14 \\
$>15$ years & 10 \\
$\quad$ Mean (months) & 60.35 \\
$\quad$ Median & 16 \\
Mode of Ventilation & \\
Invasive mechanical ventilation & 80 \\
Non-invasive mechanical ventilation & 20 \\
Duration of Ventilator Use (days) & \\
Mean & 17.72 \\
Median & 16 \\
Length of Stay (days) & \\
Mean & 25.47 \\
Median & 23 \\
\hline
\end{tabular}

Table 2 showed that the majority of PICU patients were male which were 55 patients (55\%) and female were 45 patients $(45 \%)$. Based on age, the patients were divided into 5 subcategories (ranged between 1-216 months or 1 month -18 years) and it can be seen that the highest number was from the $<12$ months age group which were 41 children (41\%), followed by 1-5-years age 
group which were 25 children (25\%), 10-15-years age group which were 14 children (14\%), and 5-10-years age group and $>15$-years age group which both had the same number of 10 children $(10 \%)$.

Table 2 also showed the most frequently used ventilation mode which were invasive mechanical ventilation with 80 patients $(80 \%)$ followed by non-invasive mechanical ventilation with 20 patients $(20 \%)$. This table also showed the average duration of ventilator use in PICU patients which was 17.72 days with a median of 16 days. The Length of Stay (LOS) of PICU patients showed that on average patients were hospitalized for 25.47 days with a median of 23 days.

PARDS patients with invasive mechanical ventilation were categorized for the disease severity according to Oxygenation Index (OI) category and patients with non-invasive mechanical ventilation according to Oxygen Saturation Index (OSI). The distribution of disease severity of PARDS patients according to OI category is presented on Table 3 below.

Table 3. Distribution of disease severity of PARDS patients according to OI category

\begin{tabular}{ccc}
\hline Severity & Frequency $(\mathbf{n})$ & Percentage $(\boldsymbol{\%})$ \\
\hline At risk & 57 & 71.3 \\
Mild & 21 & 26.3 \\
Moderate & 2 & 2.5 \\
Severe & 0 & 0 \\
\hline Total & $\mathbf{8 0}$ & $\mathbf{1 0 0}$ \\
\hline
\end{tabular}

Table 3 showed that from 80 patients with invasive mechanical ventilation, there were 57 patients (71.31\%) were at risk PARDS, 21 patients (26.3\%) with mild PARDS, 2 patients (2.5\%) with moderate PARDS, and there was no $(0 \%)$ patient with severe PARDS.

The distribution of disease severity of PARDS patients according to OSI category is presented on Table 4 below.

Table 4. Distribution of disease severity of PARDS patients according to OSI category

\begin{tabular}{ccc}
\hline Severity & Frequency $(\mathbf{n})$ & Percentage $(\%)$ \\
\hline At risk & 15 & 75 \\
Mild & 4 & 20 \\
Moderate & 1 & 5 \\
Severe & 0 & 0 \\
\hline Total & $\mathbf{2 0}$ & $\mathbf{1 0 0}$ \\
\hline
\end{tabular}

Table 4 above showed the disease severity of 20 PICU patients with non-invasive mechanical ventilation, there were 15 patients $(75 \%)$ were at risk PARDS, 4 patients $(20 \%)$ with mild PARDS, 1 patient (5\%) with moderate PARDS, and there was no $(0 \%)$ patient with severe PARDS. 
The frequency distribution of factors causing PARDS is presented on Table 5 below.

Table 5. Frequency distribution of factors causing PARDS

\begin{tabular}{ccc}
\hline Etiology & Frequency $(\mathbf{n})$ & Percentage (\%) \\
\hline Direct lung injury & 47 & 47 \\
Indirect lung injury & 51 & 51 \\
Complication of \\
ventilator use
\end{tabular}

Based on the result of the study presented on Table 5, from 100 PICU patients, the most common cause of PARDS were indirect lung injuries with an incidence of 51 (51\%), followed by direct lung injuries with an incidence of $47(47 \%)$, and the lowest number was due to complication of ventilator use (Ventilator Associated Pneumonia/ VAP) with an incidence of 2 (2\%).

The frequency distribution of direct lung injury as the cause of PARDS is presented on Table 6 below.

Table 6. Frequency distribution of direct lung injury as the cause of PARDS

\begin{tabular}{ccc}
\hline Direct Lung Injury & Frequency $(\mathbf{n})$ & Percentage $(\boldsymbol{\%})$ \\
\hline Primary pulmonary infection & 33 & 70,2 \\
Aspiration & 8 & 17 \\
Trauma & 4 & 8,5 \\
Others & 2 & 4,3 \\
\hline Total & $\mathbf{4 7}$ & $\mathbf{1 0 0}$
\end{tabular}

Direct lung injuries are classified into several groups as presented on Table 6. From 47 patients with PARDS caused by direct lung injuries, the highest incidence was due to primary pulmonary infection including pneumonia, bronchopneumonia, bronchiolitis, and tuberculosis with 33 patients $(70.2 \%)$, followed by aspiration with 8 patients (17\%), previous trauma with 4 patients $(8.5 \%)$, and the lowest number was due to other factor such as lung edema with 2 patients (4.3\%).

The frequency distribution of external factors as the cause of PARDS is presented on Table 7 below.

Table 7. Frequency distribution of external factors as the cause of PARDS

\begin{tabular}{ccc}
\hline Indirect Lung Injury & Frequency (n) & Percentage (\%) \\
\hline Sepsis & 20 & 39,2 \\
Central Nervous & 16 & 31,4 \\
System (CNS) & & \\
Post-surgery & 7 & 13,7 \\
Others & 8 & 15,7 \\
\hline Total & $\mathbf{5 1}$ & $\mathbf{1 0 0}$ \\
\hline
\end{tabular}

Table 7 showed that from 51 patients with PARDS due to external factors, they were classified in to several groups. The highest number was due to sepsis which were 20 patients $(39.2 \%)$, 
followed by central nervous system (CNS) events including meningitis, hydrocephalus, CNS infection, and status epilepticus which were 16 patients (31.4\%), due to other factors including metabolic acidosis, acquired prothrombin complex deficiency (APCD), gastroenteritis, and other factors were 8 patients (15.7\%), and the lowest number was due to post-surgery case including post laparotomy surgery and post removal of intra-abdominal tumor which were 7 patients $(13.7 \%)$.

\section{Discussion}

According to the results of the study on the characteristics of the causative factors of Pediatric Acute Respiratory Distress Syndrome (PARDS) in patients admitted to Pediatric Intensive Care Unit (PICU) of H. Adam Malik Hospital Medan from 2017 - 2020, the discussion corresponds to the distribution on the specific objectives of the study.

Based on results of the study, it can be seen that the majority of patients were male which were 55 children (55\%) and female 45 children (45\%). In accordance with a study conducted in Aga Khan University Hospital by [10], from 150 PICU patients, the majority were male which were 92 children (61.33\%) followed by female which were 58 children (38.67\%). However, in the case of PRADS, there was no gender difference on patient's clinical presentation, severity, or outcome [2].

According to the results of the study presented on Table 2, it was found that the majority of PICU patients were from the $<12$ months age group with 41 children $(41 \%)$, followed by $1-5$-years age group with 25 children (25\%), 10-15-years age group with 14 children (14\%), and 5-10-years and $>15$-years age group both with 10 children (10\%). The youngest PICU patient was 1 month and 2 days old and the oldest was 17 years 4 months and 1 day old. The average age of PICU patients in this study was 60.35 months or 5.03 years with a median of 16 months or 1 year and 4 months old. In the Pediatric Acute and Critical Care Medicine Asia Network (PACCMAN) PICU study from Singapore, Malaysia, Thailand, China, and Vietnam, it was found that patients with similar external causative factors from the older age group had a worse disease severity and had a higher risk of organ failure [11].

Table 2 showed the most frequently used ventilator mode was invasive mechanical ventilation which was in 80 patients (80\%) and non-invasive mechanical ventilation was in 20 patients $(20 \%)$. In a study by [1], from 35 patients who met the PALICC criteria, there were 31 patients with invasive mechanical ventilation $(88.6 \%)$ and 4 patients with non-invasive mechanical ventilation (11.4\%). This study also found that the average duration of ventilator use in PICU patients was 17.72 days with a median of 16 days. The length of stay of PICU patients had an average of 25.47 days with a median of 23 days.

As presented on Table 3, from a total of 80 patients with invasive mechanical ventilation, the disease severity was assessed using Oxygenation Index (OI) category, as many as 57 patients (71.3\%) were at risk PARDS, 21 patients (26.3\%) had mild PARDS, 2 patients (2.5\%) had moderate PARDS, and no patient had severe PARDS. On Table 4 for patients with non-invasive mechanical ventilation, the disease severity was assessed using Oxygen Saturation Index (OSI). From a total of 20 patients, as many as 15 patients (75\%) were at risk PARDS, 4 patients $(20 \%)$ had mild PARDS, 1 patient (5\%) had moderate PARDS, and no patient had severe PARDS.

From the study results presented on Table 5, it was found that the most common cause of PARDS was indirect lung injury which were 51 events $(51 \%)$, followed by direct lung injury which were 
47 events (47\%), and the least number was from complication of ventilator use which were 2 events $(2 \%)$.

PARDS due to direct lung injury had a lower mortality rate compared to those due to indirect lung injury, including septic shock or non-septic shock [12]. One of the complication of ventilator use is Ventilator Associated Pneumonia (VAP). VAP is defined as pneumonia that occurs 48 hours after intubation and mechanical ventilation. The diagnosis of VAP is confirmed by a positive swab culture. The most common cause of pneumonia is endogenous flora colonization in the nasopharyngeal and oropharyngeal area or exogenous pathogen which mainly comes from the ICU environment, such as the hands or clothes of health care workers, contaminated ventilator equipment, or the water and air in the hospital.

Pediatric Acute Respiratory Distress Syndrome (PARDS) is considered to be caused by specific disease processes which were classified to direct and indirect lung injury. The most common direct lung injuries are primary pulmonary infection, aspiration, and previous trauma. Table 6 showed that from a total of 47 PARDS due to direct lung injury, the highest frequency was due to primary pulmonary infection such as pneumonia, bronchopneumonia, bronchiolitis, and tuberculosis which were 33 events (70.2\%), followed by aspiration which were 8 events (17\%), previous trauma 4 events $(8.5 \%)$, and the lowest frequency was due to other factors such as lung edema which were 2 events $(4.3 \%)$.

The results of this study were in accordance with a study by Khemani et al., [12] which found that the most common cause of pneumonia or lower respiratory tract infection which were 445 of 708 patients $(63 \%)$, followed by aspiration which were 60 patients $(8 \%)$, and the least was risk of injury which were 27 patients (4\%). Primary pulmonary infections leading to ARDS can be related to a viral etiology, bacterial etiology, or both. Viral etiologies are those that cause the upper respiratory infections and bronchiolitis cases commonly encountered in the PICU [13]. Simillary, bacterial causes of PARDS are often the common pathogens that cause communityacquired pneumonia [14].

According to the results of this study, it was found that 51 PARDS caused by indirect lung injury, the highest frequency was due to sepsis which were 20 events (39.2\%), followed by Central Nervous System (CNS) events including meningitis, hydrocephalus, CNS infection, and status epilepticus which were 16 events (31.4\%), due to other factors were 8 events (15.7\%), and the lowest frequency was due to post-surgical events including post-laparotomy surgery and intraabdominal tumor removal which were 7 events (13.7\%).

Sepsis was the most common cause of PARDS from indirect lung injury. In a study done in 145 PICU from 27 countries, 133 of 708 patients with PARDS (19\%) was caused by sepsis [12]. Endothelial activation, cytokine mediated inflammation, reactive oxygen species, and disorders of normal coagulation cascade in patients with severe sepsis could lead to diffuse alveolar damage which resulted in inflammation and cellular damage in ARDS.

\section{Conclusion}

From 100 PICU patients, it was found that the majority were male with the highest incidence in $<12$ months age group. The most frequently used ventilation mode was invasive mechanical ventilation, with an average duration of ventilator use was 17.72 days and on average, the PICU patients were hospitalized for 25.47 days. The most common severity of Pediatric Acute Respiratory Distress Syndrome (PARDS) was at risk patients both using Oxygenation Index (OI) 
and Oxygen Saturation Index (OSI) categorization. The most common causative factor of PARDS was indirect lung injuries such as sepsis and the most common direct lung injury was primary pulmonary infection.

\section{REFERENCES}

[1] S. Gupta, J. Sankar, R. Lodha, and S. K. Kabra, "Comparison of prevalence and outcomes of pediatric acute respiratory distress syndrome using pediatric acute lung injury consensus conference criteria and Berlin definition," Front. Pediatr., vol. 6, no. April, 2018, doi: 10.3389/fped.2018.00093.

[2] J. G. Kohne and H. R. Flori, "Risk Factors and Etiologies of Pediatric Acute Respiratory Distress Syndrome," Pediatr. Acute Respir. Distress Syndr., pp. 33-46, 2020, doi: 10.1007/978-3-030-21840-9_4.

[3] T. Pham and G. D. Rubenfeld, "Fifty years of research in ards the epidemiology of acute respiratory distress syndrome a 50th birthday review," Am. J. Respir. Crit. Care Med., vol. 195, no. 7, pp. 860-870, 2017, doi: 10.1164/rccm.201609-1773CP.

[4] E. Fan, D. Brodie, and A. S. Slutsky, "Acute respiratory distress syndrome advances in diagnosis and treatment," JAMA - J. Am. Med. Assoc., vol. 319, no. 7, pp. 698-710, 2018, doi: 10.1001/jama.2017.21907.

[5] R. G. Khemani, L. S. Smith, J. J. Zimmerman, and S. Erickson, "Pediatric acute respiratory distress syndrome: Definition, incidence, and epidemiology: Proceedings from the Pediatric Acute Lung Injury Consensus Conference," Pediatr. Crit. Care Med., vol. 16, no. 5, pp. S23-S40, 2015, doi: 10.1097/PCC.0000000000000432.

[6] M. W. Quasney, Y. M. López-Fernández, M. Santschi, and R. S. Watson, "The outcomes of children with pediatric acute respiratory distress syndrome: Proceedings from the Pediatric Acute Lung Injury Consensus Conference," Pediatr. Crit. Care Med., vol. 16, no. 5, pp. S118-S131, 2015, doi: 10.1097/PCC.0000000000000438.

[7] T. B. Bramantyo, S. Martuti, and P. Pudjiastuti, "Perbandingan Mortalitas Pasien Anak dengan Acute Respiratory Distress Syndrome yang Menggunakan Delta Pressure Tinggi dan Rendah," Sari Pediatr., vol. 19, no. 3, p. 156, 2018, doi: 10.14238/sp19.3.2017.15660 .

[8] R. Ahmed, A. Azim, A. Nangialay, A. Haque, and H. Jurair, "Frequency of Pediatric Acute Respiratory Distress Syndrome Based on Oxygen Saturation Index in Pediatric Intensive Care Unit of a Developing Country," Cureus, vol. 11, no. 12, pp. 8-12, 2019, doi: $10.7759 /$ cureus.6444.

[9] K. E. Orloff, D. A. Turner, and K. J. Rehder, "The Current State of Pediatric Acute Respiratory Distress Syndrome," Pediatr. Allergy, Immunol. Pulmonol., vol. 32, no. 2, pp. 35-44, 2019, doi: 10.1089/ped.2019.0999.

[10] R. Ahmed, A. Azim, A. Nangialay, A. Haque, and H. Jurair, "Frequency of Pediatric Acute Respiratory Distress Syndrome Based on Oxygen Saturation Index in Pediatric Intensive Care Unit of a Developing Country," Cureus, vol. 11, no. 12, pp. 12-18, 2019, doi: 10.7759/cureus.6444.

[11] C. S. Gan et al., "Differences between pulmonary and extrapulmonary pediatric acute respiratory distress syndrome: A multicenter analysis," Pediatr. Crit. Care Med., vol. 19, no. 10, pp. E504-E513, 2018, doi: 10.1097/PCC.0000000000001667.

[12] R. G. Khemani et al., "Paediatric acute respiratory distress syndrome incidence and epidemiology (PARDIE): an international, observational study," Lancet Respir. Med., vol. 7, no. 2, pp. 115-128, 2019, doi: 10.1016/S2213-2600(18)30344-8.

[13] R. D. Shah and R. G. Wunderink, "Viral Pneumonia and Acute Respiratory Distress Syndrome," Clin. Chest Med., vol. 38, no. 1, pp. 113-125, 2017, doi: 
10.1016/j.ccm.2016.11.013.

[14] L. Papazian et al., "Diagnostic workup for ARDS patients," Intensive Care Med., vol. 42, no. 5, pp. 674-685, 2016, doi: 10.1007/s00134-016-4324-5. 